Süleyman Demirel Üniversitesi Fen Edebiyat Fakültesi Fen Dergisi

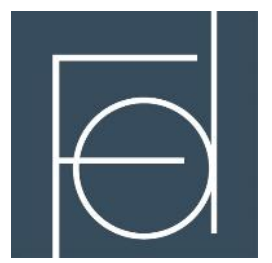

Süleyman Demirel University Faculty of Arts and Sciences Journal of Science

2021, 16(2): 458-467

DOI: $10.29233 /$ sdufeffd.996484

Atıf için / For Citation: H. Öztürk, N. Yorulmaz, M. Durgun, Z. Şilan Turhan, İ. H. Sarpun, "Determination of Antibacterial Properties of Some Sulfonamide Compounds by Molecular Docking", Süleyman Demirel Üniversitesi Fen Edebiyat Fakültesi Fen Dergisi, 16(2), 458-467, 2021.

Research Article

\title{
Determination of Antibacterial Properties of Some Sulfonamide Compounds by Molecular Docking
}

\author{
Hilal ÖZTÜRK ${ }^{* 1,2}$, Nuri YORULMAZ ${ }^{3}$, Mustafa DURGUN ${ }^{4}$, Zeynep Şilan TURHAN ${ }^{5}$, İsmail \\ Hakk1 SARPUN $^{6}$
}

${ }^{1}$ Karadeniz Technical University, Medicine Faculty, Biophysics Department, 61080, Trabzon, Turkey

${ }^{2}$ Istanbul University-Cerrahpaşa, Medicine Faculty, Biophysics Department, 34098, Istanbul, Turkey

${ }^{3}$ Harran University, Physics Department, 63300, Şanliurfa, Turkey

${ }^{4}$ Harran University, Chemistry Department,63300, Şanliurfa, Turkey

${ }^{5}$ Iğdır University, Biochemistry Department, 76000, Turkey

${ }^{6}$ Akdeniz University, Physics Department, 07070, Antalya, Turkey

*yazışllan yazar e-posta: hilal.ozturk@ktu.edu.tr

(Received: 16.09.2021, Accepted: 01.11.2021, Published: 25.11.2021)

\begin{abstract}
Prontosil, the sulfonamide compound that started the antibacterial era, was the first commercially available antibacterial agent. Sulfonamide functional groups have gained importance in medicinal chemistry since the first announcement of antibacterial drugs. Synthetic sulfonamides are generally used for the treatment of bacterial infections in biological systems, as well as antifungal, anti-inflammatory antioxidant, diuretics, carbonic anhydrases, antitumor and so on. It has aroused high curiosity in biology and medicine due to its wide range of biological applications.

In this study, molecular docking studies were applied to investigate the potential antibacterial properties of sulfonamide derivative compounds synthesized in previous study. The binding energies was anaylzed by Autodock 4.2 code which also performed molecular docking. Docking simulations of sulfonamide compounds at the active site of $E$. coli $\beta$-ketoacyl-acyl carrier protein synthase III (KAS III, PDB ID: 1HNJ) were performed to determine possible binding patterns and inhibitory effects. Docking results were also compared with triclosan used as a commercial antibacterial agent. Biovia Discovery Studio Visualizer 2020 and Autodock 4.2 software were used to analyze results of molecular docking.

The binding energies of 3, 4, 5 and 6 sulfonamides used in the study to KAS III enzyme were found to be $-6.94,-7.22,-7.76,-8.13$, respectively. As a result of molecular docking study, these sulfonamide derivatives may have potential antibacterial properties.
\end{abstract}

Key words: Molecular docking, Sulfonamide, Antibacterial properties

Hilal ÖZTÜRK, hilal.ozturk@ktu.edu.tr, ORCID: https://orcid.org/0000-0003-0079-5184

Nuri YORULMAZ, nyorulmaz@harran.edu.tr, ORCID: https://orcid.org/0000-0003-4959-2302

Mustafa DURGUN, mustafadurgun@ harran.edu.tr, ORCID: https://orcid.org/0000-0003-3012-7582

Zeynep Şilan TURHAN, zeynep.turhanirak@igdir.edu.tr, ORCID: https://orcid.org/ 0000-0002-3587-

2576

İsmail Hakk1 SARPUN, sarpun@akdeniz.edu.tr , ORCID: https://orcid.org/ 0000-0002-9788-699X 


\section{Bazı Sülfonamid Bileşiklerinin Moleküler Yerleştirme Yöntemiyle Antibakteriyel Özelliklerinin Belirlenmesi}

Öz: Antibakteriyel çağı başlatan sülfonamid bileşiği olan Prontosil, ticari olarak temin edilebilen ilk antibakteriyel ajandır. Sülfonamid fonksiyonel grupları, antibakteriyel ilaçların ilk duyurulmasından bu yana tıbbi kimyada önem kazanmıştır. Sentetik sülfonamidler genel olarak biyolojik sistemlerdeki bakteriyel enfeksiyonların tedavisinde kullanıldığı gibi mantar önleyici, iltihap önleyici antioksidan, diüretikler, karbonik anhidrazlar, antitümör vb olarakta kullanılmaktadırlar. Çok çeşitli biyolojik uygulamaları nedeniyle biyoloji ve tıpta yüksek merak uyandırmıştır.

$\mathrm{Bu}$ çalışmada, daha önceki bir çalışmada sentezlenen sülfonamid türevi bileşiklerin potansiyel antibakteriyel özelliklerini araştırmak için moleküler yerleştirme çalışmaları uygulanmıştır. Kenetlenme olasılığ 1 , moleküler yerleştirmeyi de gerçekleştiren Autodock 4.2 kodu ile analiz edildi. E. coli $\beta$-ketoasil-asil taşıyıcı protein sentaz III'ün (KAS III, PDB ID: 1HNJ) aktif bölgesindeki sülfonamid bileşiklerinin yerleştirme simülasyonları, olası bağlanma modellerini ve engelleyici etkileri belirlemek için gerçekleştirilmiştir. Yerleştirme sonuçları, ticari bir antibakteriyel madde olarak kullanılan triklosan ile de karşılaştırıldı. Moleküler yerleştirme sonuçlarını analiz etmek için Biovia Discovery Studio Visualizer 2020 ve Autodock 4.2 yazılımı kullanıldı.

Çalışmada kullanılan 3, 4, 5 ve 6 isimli sülfanamidlerin KAS III enzimine bağlanma enerjileri sırasıyla $-6,94,-7,22,-7,76,-8,13$ bulunmuştur. Moleküler docking çalışmasının sonucu bu sülfonamid türevlerinin potansiyel antibakteriyel özelliğe sahip olabileceğini göstermiştir.

Anahtar kelimeler: Moleküler yerleştirme, Sülfonamid, Antibakteriyel özellikler 


\section{Introduction}

$\beta$-Ketoacyl-acyl carrier protein (ACP) synthase III (EC 2.3.1.180) (FabH or KAS III) enzyme is one of the enzymes that has a great importance in the formation of the first step of bacterial fatty acid biosynthesis that occurs in plant and bacterial varieties [1]. KAS III enzymes catalyze the condensation reaction between an acetyl group attached to $\mathrm{CoA}$ and a malonyl group attached to an ACP, resulting in the production of acetoacetyl-ACP [2]. The condensation reaction catalyzed by the KAS III enzyme is necessary for the initiation of fatty acid synthesis and thus the survival of many bacteria. Many bacteria, such as E. coli, whose KAS III enzyme is inhibited, lose their ability to synthesize fatty acids [3]. This important role of the KAS III enzyme in this pathway has led to its investigation as a drug target. Therefore, KAS enzymes have been the subject of many studies and many compounds that inhibit this enzyme have been identified [4-9]. The crystal structure of the KAS III enzyme and definition the active site of the enzyme are explained in these studies [10-13]. Besides X-ray crystallography, molecular dynamics simulations and molecular docking studies are available in the literature to investigate the conformation of both ligand-free E. coli KAS III and an enzyme-inhibitor complex with a more accurate inhibitor modeling [14]. In the literature, there are enzymes such as thiolactomycin (TLM), isoniazid (isonicotinic acid hydrazide), ethionamide and triclosan [5-chloro-2-(2,4-dichlorophenoxy)-phenol] that inhibit the biosynthesis mechanism of fatty acids [15]. Research continues on the discovery of new TLM molecule derivatives and related compounds, which make this inhibition mechanism easier and faster [16-18]. It is thought that synthesizing such molecules will be easier and cheaper.

Sulfonamides and their derivatives have an important place in biology and medicine. Sulfonamides are bacteriostatic and inhibit the growth and reproduction of bacteria. The first antibacterial drug on the market was a sulfonamide compound called Prontosil [19]. Although sulfonamides are generally used in the treatment of bacterial infections, they have been used in many areas such as anticancer, Alzheimer's diseases, anti-HIV inhibitors, antiviral and antimalarial [20-26]. In addition to laboratory studies, computer aided modeling and docking studies have made it easier to determine the effects of new sulfonamide derivatives on different enzymes. Molecular docking may be the most frequently used one in this type of research, as it provides high-accuracy predictions about the interaction of molecules with each other.

Molecular docking, which is a common method to describe the bond structure formed between a macromolecule and a small molecule, frequently used in structure-based rational drug design. This method allows us to predict the type of interaction between molecules for protein-ligand or protein-protein structures. It also gives information about protein inhibition or activation. It is necessary to know the active site of the protein and its interaction with other molecules, to perform docking studies correctly [27]. As a result of the docking process, intermolecular effects such as steric, hydrophobic and electrostatic are detected and optimized. Thus the optimal binding energy of the ligand to the protein is calculated [28]. Research continues on the effectiveness of inhibitors using the molecular docking method. For example, studies on Covid19 mainprotease, acetylcholinesterase, $\alpha$-glycosidase, human paraoxonase-I and human carbonic anhydrase inhibitors have been published [29-34].

In this study, some sulfonamide derivatives synthesized in the previous study were used. The effect of these sulfonamide derivatives, which have been shown to have antimicrobial effects in microbial culture studies [22], on the KAS III enzyme is 
unknown. Therefore, we investigated the binding sites (amino acid residues) and binding energies of these molecules on KAS III using the molecular docking method.

\section{Materials and Methods}

KAS III data was obtained from Protein Databank (PDB ID: 1HNJ). The crystal structure of KAS III + Malonyl-CoA is given in Figure 1. Novel 4-(2-methylacetamide) benzene sulfonamide derivatives and triclosan were used as ligands. Triclosan is used as a commercial antibacterial agent and was chosen as our reference molecule in this study. The 2D structures and names of these compounds are given in Table 1 . The sulfonamide derivatives' names are the same as in the previous study [22]. All compounds were selected with the Avogadro 1.2 program and MMFF94 force field, optimized for 3D structures prepared with ChemSketch 2019 free software and converted to mol2 file format [35].

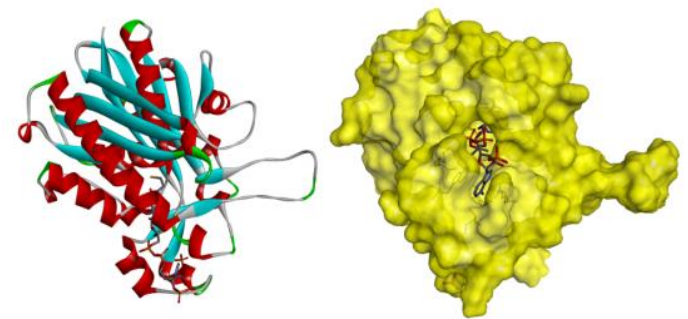

Figure 1. Target protein structure with Malonyl-CoA (PDB ID: 1HNJ)

Molecular docking studies were performed using Autodock 4.2 [36]. Each docking was performed according to standard Autodock steps [37]. The grid box coordinates and size parameters are 126x126x126 and 26.233, 25.913, 22.182, respectively. Simulations of insertion of sulfonamide compounds into the active site of E. coli KAS III were performed to identify possible binding patterns and inhibitory effects. The most suitable of the possible binding modes obtained as a result of the Molecular Docking processes were determined with Autodock 4.2, and their analyzes and visuals were obtained with the Biovia Discovery Studio Visualizer 2020 program.

Table 1. The structure of the sulfonamide compounds and triclosan

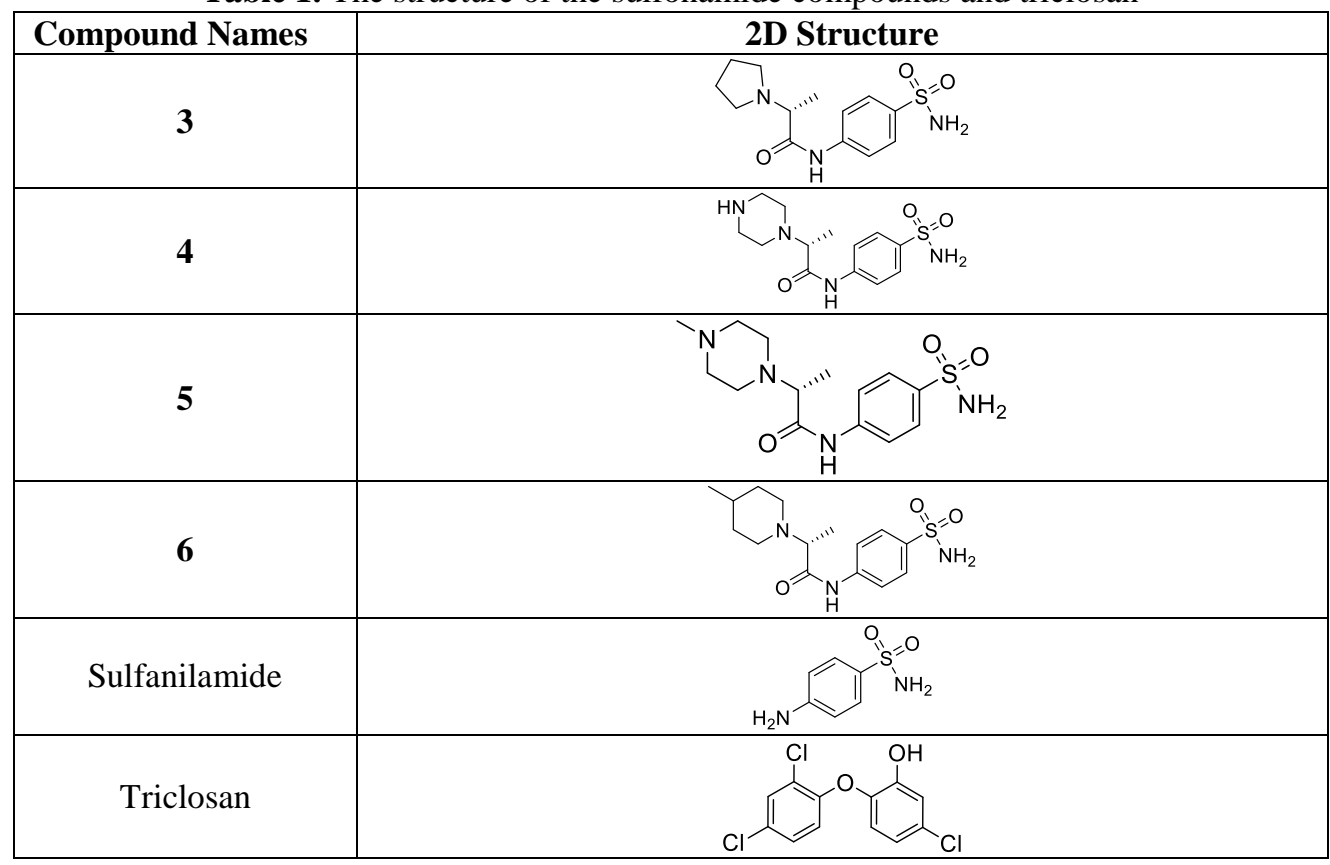




\section{Results and Discussion}

Docking operations were performed and evaluated in accordance with the literature as described in the material method [29,30,34]. Molecular docking results on KAS III inhibition of sulfonamide molecules and triclosan, which is a commercial antibacterial agent, are shown in Table 2-4. All studied compounds showed significant binding affinity to KAS III (Table 2). The most stable structures of the molecules studied with KAS III were determined according to the binding energy and the interaction of the molecule with the active site. Additionally, hydrogen bonds at the binding site were analyzed $[38,39]$.

Table 3 shows the most suitable binding site selected by molecular docking. Sulfonamide compounds and triclosan molecules are bound to the active site of the KAS III enzyme. Table 4 shows the binding of the ligands with the key amino acids of the KAS III enzyme in 2D.

Table 2. Molecular docking analysis of the sulfonamide compounds and triclosan

\begin{tabular}{|c|c|c|c|c|c|}
\hline Protein & Compound & $\begin{array}{c}\text { Binding Energy } \\
(\Delta \mathbf{G}) \\
(\mathrm{kcal} / \mathrm{mol}) \\
\end{array}$ & $\begin{array}{c}\text { Inhibition } \\
\text { Constant } \\
K \mathbf{K i} \\
\end{array}$ & Hydrogen Bond & $\begin{array}{c}\text { Lenght } \\
\text { Angström }(\AA)\end{array}$ \\
\hline \multirow{6}{*}{$1 \mathrm{HNJ}$} & 3 & -6.94 & $8.18 \mu \mathrm{M}$ & $\begin{array}{l}\text { ASN247:ND2 - } \\
\text { O } \\
\text { ASN274:ND2 - } \\
\text { O } \\
\text { PHE304:O - H } \\
\text { PHE304:O - H }\end{array}$ & $\begin{array}{l}2.97 \\
3.17 \\
2.16 \\
2.38\end{array}$ \\
\hline & 4 & -7.22 & $5.12 \mu \mathrm{M}$ & $\begin{array}{l}\text { ASP150:OD2 - H } \\
\text { ASN247:ND2 - } \\
\text { O } \\
\text { ALA246:O - H } \\
\text { ALA246:O - H }\end{array}$ & $\begin{array}{l}1.96 \\
3.02 \\
2.36 \\
2.22\end{array}$ \\
\hline & 5 & -7.76 & $2.05 \mu \mathrm{M}$ & $\begin{array}{l}\text { PHE213:N - O } \\
\text { GLY209:O - H } \\
\text { ARG36:NH2 - O } \\
\text { ARG36:O - H } \\
\text { ARG36:O - H }\end{array}$ & $\begin{array}{l}3.24 \\
1.99 \\
3.12 \\
2.19 \\
2.18\end{array}$ \\
\hline & 6 & -8.13 & $1.10 \mu \mathrm{M}$ & $\begin{array}{l}\text { ASN247:ND2 - } \\
\text { O } \\
\text { ALA246:O - H } \\
\text { ALA246:O - H }\end{array}$ & $\begin{array}{l}2.89 \\
2.15 \\
2.23\end{array}$ \\
\hline & Sulfanilamide & -4.84 & $282.82 \mu \mathrm{M}$ & $\begin{array}{l}\text { GLY152:O - H } \\
\text { ARG36:NH2 - O } \\
\text { ARG249:HH2 - } \\
\text { O } \\
\text { ARG249:HH2 - } \\
\text { N } \\
\text { ARG36:O - H } \\
\text { ARG36:O - H }\end{array}$ & $\begin{array}{l}2.32 \\
3.11 \\
3.01 \\
3.39 \\
2.22 \\
2.06\end{array}$ \\
\hline & Triclosan & -7.08 & $6.48 \mu \mathrm{M}$ & GLY209:O - H & 2.10 \\
\hline
\end{tabular}


Table 3. The binding sites in the pocket of protein (1HNJ)

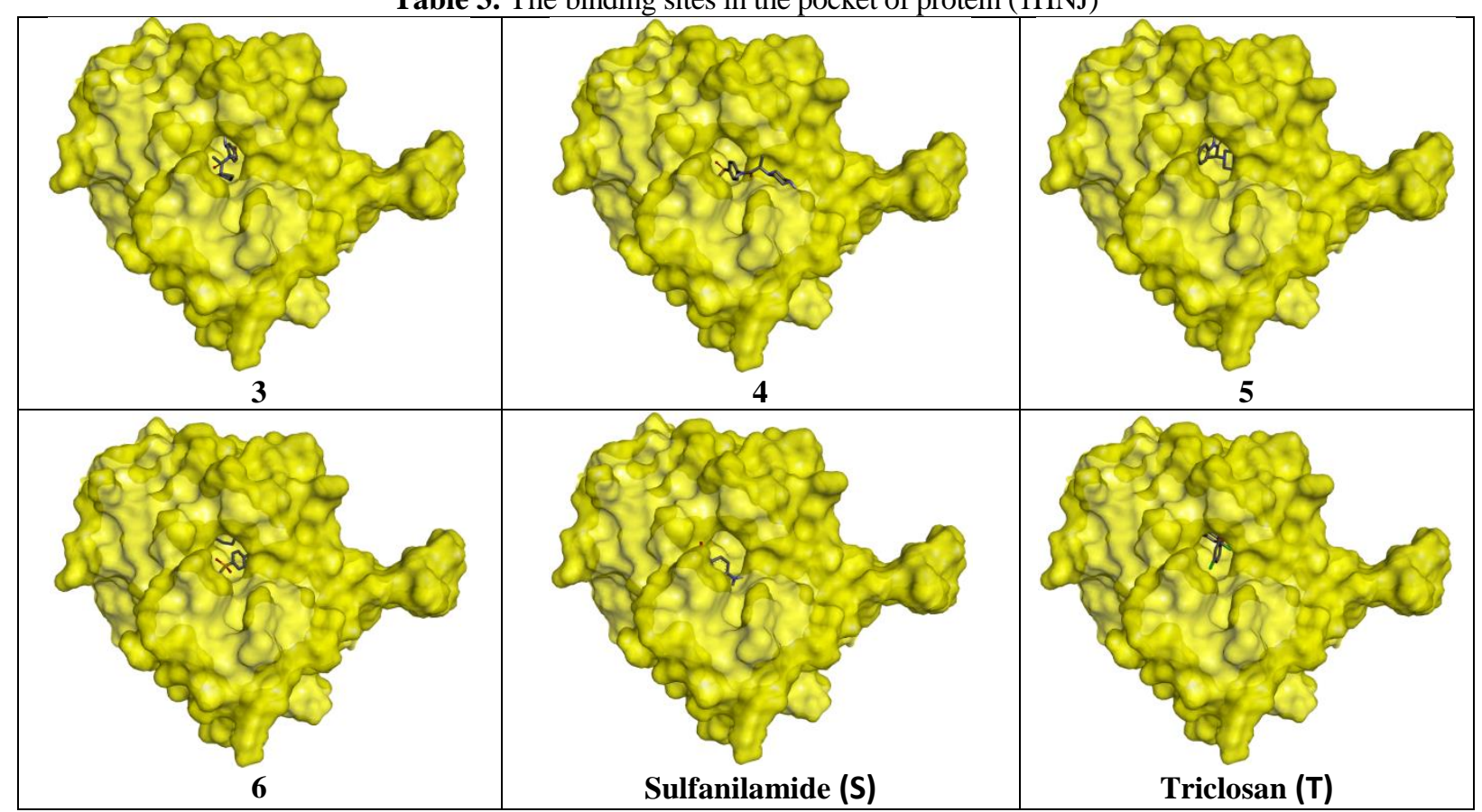

Table 4. 3D and 2D interaction of compounds with the amino acids of the KAS III binding site.

3




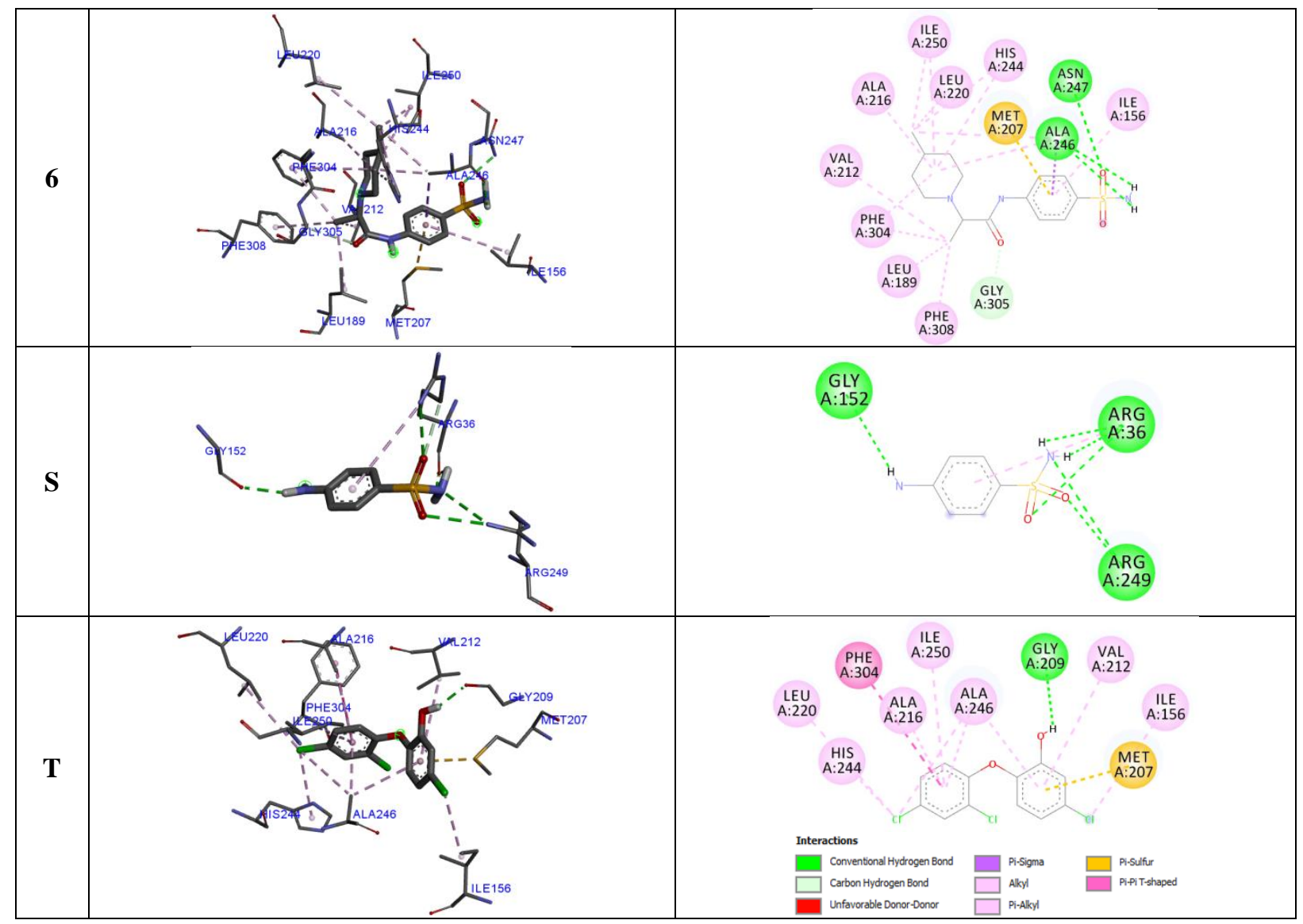

The number and length of hydrogen bonds formed with the active site of the molecule is one of the most important data in docking studies. As shown in Table 2, H-bonds play a key role in the stability of the enzyme-ligand complex formed. Ligands with more negative binding energies bind more strongly to the protein. Molecular docking results showed that all sulfonamide compounds bind with the active site of the enzyme by forming hydrogen bonds. The binding scores of molecules 4, 5 and 6 which are -7.22, $7.76,-8.13 \mathrm{kcal} / \mathrm{mol}$ respectively, are higher than the standard drug $(-7.08 \mathrm{kcal} / \mathrm{mol}$ for T). The amino acids Thr28, Trp32, Arg151, Ile155, Arg36, Gly152, Asn210, Asn274, Arg249, Ile156, Ala246, Leu189, Thr37, Met207, Gly209, Asn247, Phe213, and Phe304 are in the active site of KAS III+Malonyl-CoA. However the active site Arg36, Arg151, Trp32, Thr28 and Asn247 amino acid residues in the pocket of the 1HNJ protein play the most important roles.

Molecular docking analysis shows that the interactions of sulfonamide derivatives with amino acid residues at the active sites of the protein are the same as where Triclosan binds (Table 4). These interactions are also compatible with the literature [38-40]. A hydrogen bond interaction with a bond length of $2.10 \AA$ was observed between the proton of the $-\mathrm{OH}$ group of Triclosan and the Oxygen of the amino acid Gly209 of the KASIII protein. Other interactions are given in Table 4. In the sulfonamide-KAS III complex, a hydrogen bond interaction has occurred between Asn247, Asn274, and Phe304 with the compound 3, Asp150, Asn247, and Ala246 with the compound 4, Phe213, Gly209, and Arg36 with the compound 5, ASN247, ALA246 with the compound 6, Gly152, Arg36, and Arg249 with the compound S. Considering the binding energies of the reference molecule triclosan and sulfonamide derivatives $\mathbf{( 4 , 5}$ and 6) with the target protein KAS III, sulfonamide derivatives can be used as antibacterial agents.

\section{Conclusions and Comment}


Sulfonamides have an increasing importance in medicinal chemistry due to their use as antibacterial. Molecular docking researches were applied to determine the potential antibacterial properties of sulfonamide derivative compounds. Docking simulations of sulfonamide compounds at the active site of $E$. coli KAS III were performed to determine possible binding patterns and inhibitory effects. Docking results were also compared with triclosan used as a commercial antibacterial agent. Molecular docking methods have compatible results for some molecules in terms of binding score $(-7.22$ $\mathrm{kcal} / \mathrm{mol}$ for $4,-7.76 \mathrm{kcal} / \mathrm{mol}$ for 5 , and $-8.13 \mathrm{kcal} / \mathrm{mol}$ for 6 ) compared to standard drugs $(-7.08 \mathrm{kcal} / \mathrm{mol}$ for Triclosan). It has been observed that the sulfonamide derivatives of molecular docking analyzes and the Triclosan compound used as a standard interact with residues in the active sites of the protein. The findings from this study indicate that sulfonamide compounds 4,5 and 6 may have the potential to be used as antibacterial.

\section{Author Statement}

Hilal Öztürk: Investigation, Original Draft Writing.

Nuri Yorulmaz: Methodology, Software

Mustafa Durgun: Resource/Metarial Instrument Supply,

Zeynep Şilan Turhan: Formal Analysis.

İsmail Hakk1 Sarpün: Supervision, Observation, Advice.

\section{Acknowledgement}

This study was partly presented at the ICETAS 2020 Conference.

\section{Conflict of Interest}

As the authors of this study, we declare that we do not have any conflict of interest statement.

\section{Ethics Committee Approval and Informed Consent}

As the authors of this study, we declare that we do not have any ethics committee approval and/or informed consent statement.

\section{References}

[1] J.E. Cronan Jr, C.O. "Rock, biosynthesis of membrane lipids, E. coli and Salmonella, Cellular and Molecular Biology,” ASM Press, Washington, DC, pp. 612-638, 1996.

[2] J.L. Garwin, A.L. Klages, J.E. Cronan Jr, "Structural, enzymatic, and genetic studies of $\beta$ ketoacyl-acyl carrier protein synthases I and II of Escherichia coli," J. Biol. Chem., 255, pp. 11949-11956, 1980.

[3] Q. Meng, H. Liang, H. Gao. "Roles of multiple KAS III homologues of Shewanella oneidensis in initiation of fatty acid synthesis and in cerulenin resistance," Biochimica et Biophysica Acta (BBA)-Molecular and Cell Biology of Lipids, 2018, 1863 (10), 1153-1163, 2018.

[4] J.Y. Lee, K.W. Jeong, J.U. Lee, D.I. Kang, Y. Kim, "Novel E. coli beta-ketoacyl-acyl carrier protein synthase III inhibitors as targeted antibiotic," Bioorg Med Chem., 17 (4), 1506-13, 2009.

[5] P. C. Lv, K.R. Wang, Y. Yang, W.J. Mao, J. Chen, J. Xiong, H.L. Zhu, "Design, synthesis and biological evaluation of novel thiazole derivatives as potent FabH inhibitors," Bioorg Med Chem Lett., 19 (23), 6750-4, 2009.

[6] P. C. Lv, J. Sun, Y. Luo, Y. Yang, H.L. Zhu, "Design, synthesis, and structure-activity relationships of pyrazole derivatives as potential FabH inhibitors." Bioorg Med Chem Lett., 20 (15), 4657-60, 2010. 
[7] L. Shi, R.Q. Fang, Z.W. Zhu, Y. Yang, K. Cheng, W.Q. Zhong, H.L. Zhu, "Design and synthesis of potent inhibitors of beta-ketoacyl-acyl carrier protein synthase III (FabH) as potential antibacterial agents," Eur J Med Chem., 45 (9), 4358-64, 2010.

[8] H.Q. Li, Y. Luo, H.L. Zhu, "Discovery of vinylogous carbamates as a novel class of $\beta$-ketoacylacyl carrier protein synthase III (FabH) inhibitors," Bioorg Med Chem., 19 (15), 4454-9, 2011.

[9] H.J. Zhang, D.D. Zhu, Z.L. Li, J. Sun, H.L. Zhu, "Synthesis, molecular modeling and biological evaluation of $\beta$-ketoacyl-acyl carrier protein synthase III (FabH) as novel antibacterial agents," Bioorg Med Chem., 19 (15), 4513-9, 2011.

[10] K.S. Gajiwala, S. Margosiak, J. Lu, J. Cortez, Y. Su, Z. Nie, K. Appelt, "Crystal structures of bacterial FabH suggest a molecular basis for the substrate specificity of the enzyme, "FEBS Lett., 583 (17), 2939-46, 2009.

[11] M.M. Alhamadsheh, F. Musayev, A.A. Komissarov, S. Sachdeva, H.T. Wright, N. Scarsdale, G. Florova, K. A. Reynolds, "Alkyl-CoA disulfides as inhibitors and mechanistic probes for FabH enzymes," Chem Biol., 14 (5), 513-24, 2007.

[12] R.A. Daines, I. Pendrak, K. Sham, G.S. Van Aller, A.K. Konstantinidis, J.T. Lonsdale, C.A. Janson, X. Qiu, M. Brandt, S. S. Khandekar, C. Silverman, M.S. Head, "First X-ray cocrystal structure of a bacterial FabH condensing enzyme and a small molecule inhibitor achieved using rational design and homology modeling," J Med Chem., 46 (1), 5-8, 2003.

[13] C. Davies, R. J. Heath, S. W. White, C. O. Rock, "The 1.8 A crystal structure and active-site architecture of beta-ketoacyl-acyl carrier protein synthase III (FabH) from escherichia coli," Structure, 8 (2), 185-95, 2000.

[14] Y. Perez-Castillo, M. Froeyen, M.A. Cabrera-Perez, A. Nowe, "Molecular dynamics and docking simulations as a proof of high flexibility in E. coli FabH and its relevance for accurate inhibitor modeling," J Comput Aided Mol Des., 25 (4), 371-93, 2011.

[15] E. K. Schroeder, N. de Souza, D. S. Santos, J. S. Blanchard, L. A. Basso, "Drugs that inhibit mycolic acid biosynthesis in Mycobacterium tuberculosis," Curr Pharm Biotechnol., 3 (3), 197225, 2002.

[16] S. J. Senior, P. A. Illarionov, S. S. Gurcha, I. B. Campbell, M. L. Schaeffer, D. E. Minnikin, G. S. Besra, "Biphenyl-based analogues of thiolactomycin, active against Mycobacterium tuberculosis mtFabH fatty acid condensing enzyme," Bioorg. Med. Chem. Lett., 13 (21), 3685-8, 2003.

[17] X. He, A. M. Reeve, U. R. Desai, G. E. Kellogg, K. A. Reynolds, "1,2-Dithiole-3-Ones as Potent Inhibitors of the Bacterial 3-Ketoacyl Acyl Carrier Protein Synthase III (FabH)," Antimicrob. Agents Chemother, 48 (8), 3093-102, 2004.

[18] Q. Al-Balas, N. G. Anthony, B. Al-Jaidi, A. Alnimr, G. Abbott, A. K. Brown, R. C. Taylor, G. S. Besra, T. D. McHugh, S. H. Gillespie, B. F. Johnston, S. P. Mackay, G. D. Coxon, "Identification of 2-Aminothiazole-4-Carboxylate Derivatives Active against Mycobacterium tuberculosis H37Rv and the $\beta$-Ketoacyl-ACP Synthase mtFabH,”. Plos One, 4 (5), e5617, 2005.

[19] G. Domagk, "Ein Beitrag zur Chemotherapie der bakteriellen Infektionen," Deutsch. Med. WSCHR., 61 (7), 250, 1935.

[20] M. Durgun, H. Turkmen, M. Ceruso, C. T. Supuran, "Synthesis of Schiff base derivatives of 4(2-aminoethyl)-benzenesulfonamite with inhibitory activity against carbonic anhydrase isoforms I, II, IX and XII,” Bioorganic and Medicinal Chemistry Letters, 25 (11), 2377-2381, 2015.

[21] M. Durgun, H. Turkmen, M. Ceruso, C. T. Supuran, "Synthesis of 4-sulfamoylphenylbenzylamine derivatives with inhibitory activity against human carbonic anhydrase isoforms I, II, IX and XII,” Bioorganic and Medicinal Chemistry, 24 (5), 982-988, 2016.

[22] M. Durgun, H. Turkmen, G. Zengin, H. Zengin, M. Koyunsever, I. Koyuncu, "Synthesis, characterization, in vitro cytotoxicity and antimicrobial investigation and evaluation of physicochemical properties of novel 4-(2-methylacetamite) benzenesulfonamite derivatives," Bioorganic chemistry, 70, 163-172, 2017.

[23] M. Durgun, C. Türkeş, M. Işik, Y. Demir, A. Sakli, A. Kuru, A. Güzel, Ş. Beydemir, S. Akocak, S. M. Osman, Z. Alothman, C. T. Supuran, "Synthesis, characterisation, biological evaluation and in silico studies of sulphonamide Schiff base," Journal of enzyme inhibition and medicinal chemistry, 35 (1), 950-962, 2020.

[24] I. Koyuncu, A. Gonel, M. Durgun, A. Kocyigit, O. Yuksekdag, C. T. Supuran, “Assessment of the antiproliferative and apoptotic roles of sulfonamite carbonic anhydrase IX inhibitors in HeLa cancer cell line," Journal of enzyme inhibition and medicinal chemistry, 34 (1), 75-86, 2019. 
[25] I. Koyuncu, A. Gonel, A. Kocyigit, E. Temiz, M. Durgun, C. T. Supuran, "Selective inhibition of carbonic anhydrase-IX by sulphonamite derivatives induces $\mathrm{pH}$ and reactive oxygen speciesmediated apoptosis in cervical cancer HeLa cells," Journal of enzyme inhibition and medicinal chemistry, 33 (1), 1137-1149, 2018.

[26] A. Kołaczek, I. Fusiarz, J. Ławecka, D. Branowska, "Biological activity and synthesis of sulfonamide derivatives: a brief review," Chemik, 68 (7), 620-628, 2014.

[27] D. A. Fedorovna, S. E. Georgievna, R. E. Nikolaevna, L.T. Mikhailovna, G. I. Urievna, "Supply Chain Of Promotion: From A New Substance To A Drug," Methods and problems of practical application, 150, 2019.

[28] J. A. Read, V. J. Winter, C. M. Eszes, R. B. Sessions, R. L. Brady, "Structural basis for altered activity of M-and H-isozyme forms of human lactate dehydrogenase," Proteins: Structure, Function, and Bioinformatics, 43 (2), 175-185, 2011.

[29] E. Büyükfırat, M. Durgun, N. Yorulmaz, İ. Koyuncu, M. A. Karahan, A. Gonel, V. F. Pehlivan, "Interactions Between Sedative, Analgesic and Anaesthetic Drugs with SARS-CoV-2, ACE-2 and SARS-CoV-2- ACE-2 Complex," J Turk Soc Intens Care, DOI:10.4274/tybd.galenos.2021.69885

[30] İ. Koyuncu, M. Durgun, N. Yorulmaz, S. Toprak, A. Gonel, N. Bayraktar, M. Caglayan, "Molecular Docking Demonstration of the Liquorice Chemical Molecules on the Protease and ACE2 of COVID-19 Virus", Current Enzyme Inhibition, 17 (2), 98-110, 2021.

[31] M. Işık, S. Akocak, N. Lolak, P. Taslimi, C. Türkeş, İ. Gülçin, M. Durgun, Ş. Beydemir, Ş, "Synthesis, characterization, biological evaluation, and in silico studies of novel 1,3diaryltriazene-substituted sulfathiazole derivatives," Archiv Der Pharmazie, 353 (9), p.2000102, 2020.

[32] S. Akocak, P. Taslimi, N. Lolak, M. Işık, M. Durgun, Y. Budak, C. Türkeş, İ. Gülçin, Ş. Beydemir, "Synthesis, Characterization, and Inhibition Study of Novel Substituted Phenylureido Sulfaguanidine Derivatives as $\alpha$-Glycosidase and Cholinesterase Inhibitors," Chemistry \& Biodiversity, 18 (4), p.e2000958, 2021.

[33] M. Işık, Ş. Beydemir, Y. Demir, M. Durgun, C. Türkeş, A. Nasır, A. Necip, M. Akkuş, "Benzenesulfonamide derivatives containing imine and amine groups: Inhibition on human paraoxonase and molecular docking studies," International journal of biological macromolecules, 146, 1111-1123, 2020.

[34] N. Yorulmaz, O. Oltulu, E. Eroğlu, "Development of selective QSAR models and molecular docking study for inhibitory activity of sulfonamide derivatives against carbonic anhydrase isoforms II and IX," Journal of Molecular Structure, 1163, 270-9, 2018.

[35] M. D. Hanwell, D. E. Curtis, D. C. Lonie, T. Vandermeersch, E. Zurek, G. R. Hutchison, "Avogadro: an advanced semantic chemical editor, visualization, and analysis platform," Journal of cheminformatics, 4 (1), 1-17, 2012.

[36] G. M. Morris, R. Huey, W. Lindstrom, M. F. Sanner, R. K. Belew, D. S. Goodsell, A. Olson, "AutoDock4 and AutoDockTools4: Automated docking with selective receptor flexibility," J Journal of Computational Chemistry, 30 (16), 2785-91, 2009.

[37] R. Huey, G. M. Morris, S. Forli, “Using AutoDock 4 and AutoDock Vina with AutoDockTools: A Tutorial," The Scripps Research Institute Molecular Graphics Laboratory, 2012.

[38] K. Cheng, Q. Z. Zheng, Y. Qian, L. Shi, J. Zhao, H. L. Zhu, "Synthesis, antibacterial activities and molecular docking studies of peptide and Schiff bases as targeted antibiotics," Bioorganic \& medicinal chemistry, 17 (23), 7861-7871, 2009.

[39] Ç. K. Atay, T. Tilki, D. E. Bülent, "Investigation of Potential Antibacterial Properties of Some Azo Compounds by Molecular Docking Method," Süleyman Demirel Üniversitesi Fen Edebiyat Fakültesi Fen Dergisi, 14 (1), 150-154, 2019.

[40] P. Ramesh, V. Srinivasa Rao, Y. A. Hong, P. M. Reddy, A. Hu, "Molecular design, synthesis, and biological evaluation of 2-hydroxy-3-chrysino dithiocarbamate derivatives," Molecules, 24 (17), 3038, 2019. 